\title{
THE STATUS OF A DISSOLVED COMPANY
}

\author{
DENIS R. NOËL*
}

\begin{abstract}
The author reviews the two types of dissolution and revival orders which are provided for under the present Alberta Companies Act. These are then contrasted with the unique provisions of the Canada Business Corporations Act and the draft Alberta Business Corporations Act. A detailed discussion of these provisions as they pertain to rights possessed by the Crown in respect of dissolution and revivah the extinction or non-extinction of obligations owed by or to a corporation, and the retrospective effect of revival upon the rights of other parties follows.
\end{abstract}

\section{INTRODUCTION}

What is the status of a company which has been dissolved? What are the effects of dissolution and revival upon the rights, assets and liabilities of the company? What types of third party rights are acquired following a dissolution? Will these third party rights be preserved if the company is subsequently revived?

These and other issues will be examined here. As the discussion unfolds, two major topics will be focused upon. First, an attempt will be made to ascertain the present state of the law concerning the dissolution and revival of a company in Alberta and other similar jurisdictions. As the present Companies Act ${ }^{1}$ does little to resolve the major issues involved, resort will be had to the case law on the subject. Second, immediately after a discussion of each issue, some of the provisions of the Canada Business Corporations Act, ${ }^{2}$ as well as those of the new proposed Alberta Business Corporations Act, ${ }^{3}$ will be examined in order to evaluate how effective the solutions proposed or enacted in those Acts will be in resolving the difficulties and problems now existing. The Canada Business Corporations Act (hereinafter referred to as the CBCA) has been chosen because it is rapidly becoming the model act for many provincial reforms, including the proposed Alberta Business Corporations Act (hereinafter referred to as the $\mathrm{ABCA}$ ).

\section{DISSOLUTION AND REVIVAL}

\section{A. Types of Dissolution and Revival Orders}

\section{General Comments}

Before entering into any detailed discussion of the effects of dissolution and revival upon a company's assets and liabilities, it would be useful to characterize the two types of dissolution and revival orders which may oc-

* B.A., LL.B. Articling with the Alberta Court of Appeal and with Reynolds, Mirth and Cote, Edmonton. Much of the research upon which this paper is based was effected in the course of summer employment with the Institute of Law Research and Reform. The author wishes to thank W. H. Hurlburt, Q.C., Director of the Institute, and George C. Field, Director of the Company Law Project, for their permission to utilize part of that research and for their helpful comments. The usual disclaimer clause, of course, applies: all errors, omissions and defects remain solely the responsibility of the author.

1. R.S.A. 1970 , c. 60 , as am.

2. S.C. $1974-75$, c. 33 , as am.

3. Bill 85, 1980 (2nd sess.). See Institute of Law Research and Reform, Report No. 36, Vol.2, Draft Alberta Business Corporations Act, August, 1980. 
cur under The Companies Act. ${ }^{4}$ Such a discussion is necessary at this preliminary stage because different legal results may flow depending upon the type of dissolution involved.

(a) The Technical Dissolution: Sections 188, 189

Under s. 188 of The Companies Act, a company may be struck off the register for a variety of reasons:

188. (1) Where

(a) a company or an extra-provincial company

(i) has failed to file any return, notice or document required to be filed with the Registrar pursuant to this Act for two consecutive years after the return, notice or document should have been so filed, or

(ii) has not complied with an undertaking it made under section 11 . subsection (3) to dissolve or change its name within six months after the incorporaton of another company with a similar name,

or

(b) the Registrar has reasonable cause to believe that

(i) a company is not carrying on business or is not in operation, or

(ii) an extra-provincial company has ceased to carry on business in Alberta,

he shall send by mail to the company or to the extra-provincial company a letter requiring it

(c) to file any return, notice or document that has not been filed, or

(d) to comply with an undertaking given under section 11, subsection (3), or

(e) to notify the Registrar,

(i) in the case of a company, as to whether it is carrying on business or is in operation, or

(ii) in the case of an extra-provincial company, as to whether it has ceased to carry on business in Alberta.

Under s. 188(4), after the requisite notices have been given, the company may be struck off the register:

(4) At the expiration of the time mentioned in a notice prescribed under subsection (2) or (3), and also in any case where a company has by resolution requested the Registrar to strike it off the register, and has filed with him a statutory declaration of two or more directors proving that the company has no debts or liabilities, the Registrar may, unless cause to the contrary is previously shown, strike the company off the register, and shall publish notice thereof in the Alberta Gazette. and on publication the company is dissolved, or, in the case of an extra-provincial company, shall be deemed to have ceased to carry on business in the Province.

The company may then be restored to the register, and as a consequence be revived, by following the procedures outlined in $s .189(1)$ :

189. (1) Where a company or an extra-provincial company or any member or creditor thereof is aggrieved by the company having been struck off the register, the court, on the application of the company or member or creditor, may, if satisfied that the company was at the time of the striking off carring on business or in operation, or otherwise that it is just that the company be restored to the register, order the company to be restored to the register, and upon a copy of the order being filed with the Registrar the company shall be deemed to have continued in existence, or, in the case of an extra-provincial company, to be still entitled to carry on business in the Province, as if it had not been struck off, and the court may by the order give such directions and make such provisions as seem just for placing the company and all other persons in the same position as nearly as possible as if the company had not been struck off, but without prejudice to the rights of parties acquired prior to the date on which the company is restored to the register.

The terms "technical" or "qualified" dissolution have been utilized by the courts in order to describe the results flowing from striking a company off the register. Due to the presence of the words "and is dissolved" in s. 188(4), it is now clear that such a company is legally dissolved, contrary to earlier doubts expressed on the subject. ${ }^{5}$ Nevertheless, despite

4. A third type of dissolution - cancellation of incorporation by the Lieutenant Governor in Council - is utilized so rarely that it has not been considered by the courts and will not be discussed here.

5. Dadson v. Grest [1928] 1 W.W.R.286 (Sask. C.A.), where the absence of such words in the Saskatchewan Act, at the time, led the Court to conclude that a company struck off the register was not dissolved. 
these words, the trend in the cases has been to hold that a company struck off the register is not "dead for all purposes", ${ }^{6}$ hence the use of the words "technical" or "qualified" dissolution. As will become apparent later, the courts have not precisely defined for what purposes a company may be dead and for what purposes it may be alive.

\section{(b) The General Dissolution}

The second type of dissolution results from the normal winding-up procedures under The Companies Act, for example, s. 209. The only means of reviving such a dissolved company is to utilize s. 272:

272. (1) Where a company has been dissolved, the court may at any time within one year of the date of the dissolution, on an application being made for the purpose by the liquidator of the company or by any other person who appears to the court to be interested, make an order, upon such terms as the court thinks fit, declaring the dissolution to have been void, and thereupon such proceedings may be taken as might have been taken if ehe company had not been dissolved.

(2) The person on whose application the order was made shall, within seven days after the making of the order, file with the Registrar an office copy of the order, and if that person fails to do so is guilty of an offence.

It has been called by some a "general dissolution" in order to distinguish it from a technical dissolution.? The concept has no utility beyond that purpose.

\section{Difficulties with the Approach}

Some critical comments concerning the foregoing distinction would now be appropriate. As is readily apparent, the analysis is rather constrained for it is very difficult to appreciate why a dissolution under $\mathbf{s . 1 8 8}$ should differ in nature from a dissolution under any other provision of a companies act. Several reasons seem to have motivated the emergence of the two different concepts. First, the courts have attempted to mitigate the harmful effects flowing from a complete dissolution. Second, s. 189(1) itself contemplates that a dissolved company may apply for restoration of its name to the register; this implies that the company is not "dead for all purposes". Lastly, the most important factor has been the marked difference between the type of revival which occurs under s. 189(1) and that which occurs under s. 272. That is, Canadian courts, rather than focusing their attention upon the revival mechanism itself, seem to have concluded that the different wording of each revival mechanism means that a different type of dissolution was involved $a b$ initio. It is significant that the English courts, when considering sections of the English Companies Act

6. A.G. of B.C. v. Royal Bank and Island Amusement Co. [1937] S.C.R. 459 (S.C.C.); Leask Cattle Co. v.Drabble [1923] 1 W.W.R. 126 (Sask. C.A.); Montreal Trust Co. v. Boy Scouts Foundation (1978) 3 E.T.R. 1 (B.C.S.C.); In Re Higginson \& Dean [1899] 1 Q.B. 325; see also $R$. v. Lincoln Mining Syndicate Ltd. [1959] S.C.R. 736 (S.C.C.). For very similar results involving letters patent companies, see Banque Canadienne Nationale v. Sawchuk [1926] 2 W.W.R. 77 (Man. C.A.) and Kildonan Investments Ltd. v. Thompson (1917) 55 S.C.R. 272 (S.C.C.).

7. A.G. of B.C. v. Royal Bank and Island Amusement Co., supra n. 6 at 476 (per Davis J.). 
similar to our own, ${ }^{8}$ have not utilized a technical dissolution analysis; rather, they have focused upon the revival mechanism itself and its effects. ${ }^{9.10}$

Despite these criticisms, the following analysis of the existing law will continue to differentiate along the lines noted above, for the courts have proceeded, rightly or wrongly, upon such a basis.

3. $C B C A / A B C A$

The provision in the CBCA somewhat equivalent to the "striking off the register" order made under s. 188(4) of The Companies Act is s. 205:

205. (1) Dissolution by Director. - Subject to subsections (2) and (3), where a corporation

(a) has not commenced business within three years after the date shown in its certificate of incorporation.

(b) has not carried on its business for three consecutive years, or

(c) is in default for a period of one year in sending to the Director any fee, notice or document required by this Act,

the Director may dissolve the corporation by issuing a certificate of dissolution under this section or he may apply to a court for an order dissolving the corporation, in which case section 210 applies.

(2) Publication. - The Director shall not dissolve a corporation under this section until he has

(a) given one hundred and twenty days notice of his decision to dissolve the corporation to the corporation and to each director thereof; and

(b) published notice of his decision to dissolve the corporation in the Canada Gazette, in the periodical referred to in section 123 and in a newspaper published or distributed in the place where the corporation has its registered office.

(3) Certificate of dissolution. - Unless cause to the contrary has been shown or an order has been made by a court under section 239, the Director may, after expiry of the period referred to in subsection (2), issue a certificate of dissolution in prescribed form.

(4) Effect of certificate. - The corporation ceases to exist on the date shown in the certificate of dissolution.

The proposed ABCA contains a very similar provision, s. 205:

205. (1) Subject to subsections (2) and (3), if a corporation

(a) has not commenced business within 3 years after the date shown in its certificate of incorporation,

8. Companies Act, 1948 (U.K.), 11 and 12 Geo. VI, c. 38, ss. 352(1), 353(6). The section similar to our s. $189(1)$ is $s .353(6)$ and it reads as follows:

(6) If a company or any member or creditor thereof feels aggrieved by the company having been struck off the register, the court on an application made by the company or member or creditor before the expiration of twenty years from the publication in the Gazette of the notice aforesaid may, if satisfied that the company was at the time of the striking off carrying on business or in operation, or otherwise that it is just that the company be restored to the register, order the name of the company to be restored to the register, and upon an office copy of the order being delivered to the registrar for registration the company shall be deemed to have continued in existence as if its name had not been struck off; and the court may by the order give such directions and make such provisions as seem just for placing the company and all other persons in the same position as nearly as may be as if the name of the company had not been struck off.

The section similar to our s. 272 is s. 352(1); it is identical to s. 272 except that an application may be made within two years of the date of dissolution.

9. Morris v. Harris [1927] A.C. 252 (H.L.); Tymans Ltd. v. Craven [1952] 1 Q.B. 100 (Eng. C.A.): Re Lewis and Smart L td. [1954] 2 All E.R. 19 (Ch. D.). It is to be noted that the procedure declaring a dissolution to be void, s. 352(1) in the English Act, can be utilized to declare void a dissolution created by a company being struck off the register: $R e M$. Belmont \& Co. Ltd. [1952] Ch. 10; Re Test Holdings (Clifton) Ltd. [1970]Ch. 285. If such is the case, the overlap reinforces the view that the type of revival mechanism involved should not lead a court to conclude that a different type of dissolution was involved.

10. For a general discussion of the English Act, see Pennington, Company Law (2nd ed.) at 725-726; Palmer's Company Law (22nd ed.) at 939-941. 
(b) has not carried on its business for 3 consecutive years, or

(c) is in default for a period of one year in sending to the Registrar any notice or document required by this Act.

the Registrar may dissolve the corporation by issuing a certificate of dissolution under this section or he may apply to the Court for an order dissolving the corporation, in which case section 210 applies.

(2) The Registrar shall not dissolve a corporation under this section until he has

(a) given 120 days notice of his decision to dissolve the corporation to the corporation and to each director of the corporation, and

(b) published notice of his decision to dissolve the corporation in the Registrar's periodical.

(3) Unless cause to the contrary has been shown or an order has been made by the Court under section 239, the Registrar may, after expiry of the period referred to in subsection (2), issue a certificate of dissolution in prescribed form.

(4) The corporation ceases to exist on the date show $n$ in the certificate of dissolution.

Provisions for other types of dissolution, such as normal winding-up proceedings, occur, of course, in both Acts.

Revival of such a dissolved corporation is provided for by a unique revival mechanism. The two provisions are almost identical;" $\mathrm{s.202}$ of the CBCA reads as follows:

202. (1) Revival. - Where a corporation is dissolved under this Part or section 261, any interested person may apply to the Director to have the corporation revived.

(2) Articles of revival. - Articles of revival in prescribed form shall be sent to the Director.

(3) Certificate of revival. - Upon receipt of articles of revival, the Director shall issue a certificate of revival in accordance with section 255 .

(4) Rights preserved. - A corporation is revived on the date shown on the certificate of revival, and thereafter the corporation, subject to such terms as may be imposed by the Director and to the rights acquired by any person after its dissolution, has all the rights and privileges and is liable for the obligations that it would have had if it had not been dissolved.

Section 201 of the proposed ABCA is as follows:

201. (1) If a corporation is dissolved under this Part any interested person may apply to the Registrar to have the corporation revived.

(2) Articles of revival in prescribed form shall be sent to the Registrar.

(3) Upon receipt of articles of revival, the Registrar shall issue a certificate of revival in accordance with section 255 .

(4) A corporation is revived on the date shown on the certificate of revival, and thereafter the corporation, subject to any reasonable terms that may be imposed by the Registrar and to the rights acquired by any person after its dissolution, has all the rights and privileges and is liable for the obligations that it would have had if it had not been dissolved.

The question which arises, in regard to both Acts, is: will the courts continue to distinguish between a technical dissolution and a general dissolution, despite the different structure and wording involved? It is suggested that the distinction may well be laid aside due to the presence of only one type of revival order. Once a unique revival order has been introduced, much of the foundation for distinguishing between a general and a technical dissolution should be weakened. This should be further reinforced by the more stringent safeguards written into the provisions for striking a corporation off the register. For example, the CBCA requires notice to be sent to the corporation and to each director, and also requires notice to be published in several places, including a newspaper. The ABCA requires notice to the corporation and each director and publication of a notice in a proposed "Registrar's periodical".

11. The only difference is that the $\mathrm{ABCA}$ deals with revival of corporations dissolved under another Act (including The Companies Act) in a separate section: s. 202. 
If such a view wins acceptance, a consistent approach to the whole issue of the effect of dissolution and subsequent revival may emerge. The courts could then focus upon the revival mechanism itself and the real and thorny problem revival involves: third-party rights. Such a development would avoid many of the problems which will be discussed next.

\section{B. Rights of the Crown}

\section{General}

The effects of dissolution and revival of a company on its property rights can now be examined in successive stages. The first question which arises is the following: can the Crown claim the personal property of a dissolved company as bona vacantia and the real property under the concept of escheats? The answer to this question involves two substantive issues; each of these will be discussed in turn.

\section{(a) Application of the Rules in Alberta}

While the rule as to bona vacantia has been applied in numerous English and Canadian cases, doubts remain as to its application in Alberta. These doubts were created by the 1917 decision of the Alberta Court of Appeal in Embree v. Millar. ${ }^{12}$ That decision dealt with the rights of the shareholders of a dissolved company to surplus funds of the company still remaining in the hands of a manager of the company. Beck J.A. rendered the unanimous judgment of the court and refused to apply the rule as to bona vacantia. He gave the following reasons: ${ }^{3}$

\footnotetext{
It seems to me that this is not a case for the Crown to sue as alleging a trust; but for the Crown to sue for the ultimate surplus of assets of the defunct company remaining after all obligations of the company are satisfied, just as in the case of a deceased person without next of kin, the Crown would be entitled to the residue after all obligations were discharged, the residue only, in either case, being the bona vacantia.

There is no direct English authority against this view that I know of - the case cited leaves it open; and in the United States the law is stated to be as follows:

"The [alleged] doctrine of the ancient common law that the debts of a corporation, and the remedies furnished by that law for the collection of the same, die and abate with the corporation. has been repudiated by modern American courts as odious to justice; and the sound and just doctrine now is that the death of a corporation no more impairs the obligation of its contracts than does the death of a natural person, but that its assets remain a trust fund or pledge for the pay. ment of its creditors and shareholders, and that a court of equity will lay hold of those assets by its receiver or otherwise and see that they are duly collected and justly applied". $10 \mathrm{Cyc}$. tit. Corporations p. 1320.
}

Shareholders are creditors of the corporation in its winding up or dissolution after the pay. ment of all its other obligations.

I adopt this view of the law and hold that the plaintiff might properly bring the action.

The net effect of so classifying the shareholders is to prevent the rule from operating at all (except for the share of a shareholder dying intestate and without next-of-kin). This acceptance of the American position by the Alberta Court of Appeal has not, however, been echoed in 
the decisions of other courts, including the Supreme Court of Canada. ${ }^{14}$ Yet none of the later decisions have considered Embree v. Millar or fully canvassed the point. Hence, it is uncertain whether Embree v. Millar has been overruled. As such, doubts remain as to the ultimate rights of the shareholders vis-à-vis the Crown, at least in Alberta.

(b) Escheats

The numerous decisions on the subject clearly establish that all the personal property of a dissolved company passes to the Crown as bona vacantia, ${ }^{15}$ if at all, due to the doubts created by Embree v. Millar.

The authorities conflict, however, on the question of whether the real property of a dissolved company vests in the Crown (the doctrine of escheats) or reverts to the immediate grantor or donor of the land to the company. The old authorities and authors support the theory of reverter to the donor. ${ }^{16}$ These decisions are commented upon favorably in dicta by a member of the House of Lords in Morris v. Harris, ${ }^{17}$ and a 1938 Ontario decision supported the reverter theory. ${ }^{18}$ On the other hand, several decisions have cast grave doubts on the reverter theory $;^{19}$ of these, more recent authorities have offered very persuasive and extensive arguments in favor of rejecting it. ${ }^{20}$

Hence, the more modern view seems to be that both the personal and real property of a company vest in the Crown. Such a view would seem to be preferable as reflecting the commercial context in which most modern real estate transactions take place. A well-recognized exception, however, exists: property held on trust by a dissolved company remains subject to the trust, even though it may technically vest in the Crown. ${ }^{21} \mathrm{~A}$ second exception (or subsistence of the old theory of

14. Examples of the treatment of the rule as to bona vacantia in various cases are as follows: (a) Holding there is no right in the shareholders: Colchester v. Brooks (1845) 7 Q.B. 339; Lindsay Petroleum Co. v. Pardee (1875) 22 Gr. 18 (Ont. S.C.T.D.); In Re Higginson \& Dean, supra n. 6.

(b) No ruling made as to the rights of shareholders: The King v. A.G. of B.C. [1924] A.C. 213 (P.C.).

(c) Bona vacantia applied or assumed to have applied, but with no discussion of the rights of shareholders: Re Henderson's Nigel Co. (1911) 105 L.T. 370; Re Ruddington Land (1909) L.J.378; A.G. of B.C. v. Royal Bank and Island A musement Co., supra n. 6;R. v.Lincoln Mining Symdicate, supra n. 6; Re Albion Machinery Co. and Winding-Up Act [1929] 1 D.L.R. 274 (N.S.S.C.); Re Wells, Swinburne-Hanham v. Howard [1933] Ch. 29 (Eng. C.A.); Re Strathblaine Estates Ltd. [1948] Ch. 228 .

15. The authorities for this are very numerous: supra n. 14; see also Russian \& English Bank v. Baring Brothers and Co. [1936] A.C. 405 at 426 (H.L.).

16. A.G. v. Lord Gore (1740) 9 Mod. Rep. 224 at 226; Colchester v. Brooks, supra n. 14; Hastings Corp. v.Letton [1908] 1 K.B.378; Re Woking Urban Council/Basington Canal Act [1914] 1 Ch. 300; Lindsay Petroleum v. Pardee, supra n. 14; Cheshire, Modern Real Property (3d ed.) 467; Armour, Real Property (2d ed.) 299.

17. Morris v. Harris, supra n. 9 at 258-259 (per Lord Sumner).

18. Re Canadian Fertilizer Co. \& Canadian Industries Ltd. [1938] 3 D.L.R. 765 (Ont. S.C.).

19. Re Wells, Swinburne-Hanham v. Howard, supra n. 14; Re Strathblaine Estates, Ltd. supra n. 14; see also a dictum of Lord Sumner in The King v. A.G. of B.C., supra n. 14 at 219: "the principle on which bona vacantia and escheats fall to the Crown is the same. that is there being no private person entitled, the Crown takes." But note that it is also Lord Sumner who gave a contrary dictum in Morris v. Harris, supra n. 9.

20. Re Jolin et al and Lart Investments Ltd. (1978) 18 O.R. (2d) 161 (Ont. D.C.); Re Stowell. MacGregor Corporation and John MacGregor Corporation [1942] 4 D.L.R. 120 (N.B.S.C.).

21. Re Strathblaine Estates, Ltd, supra n. 14. 
reverter to the donor) may exist as well, but this is less certain. According to the most recent Canadian authority, real property donated to a charitable company will revert to the donor. ${ }^{22}$ Such an exception can be supported as being consistent with the underlying rationale due to the absence of a commercial context and due to its affinity to the first exception discussed above.

\section{The Technical Dissolution}

It will now be assumed, despite the uncertainty noted above, that the general rules as to bona vacantia and escheats apply in Alberta. Attention can thereby be focused on the effects of revival or possible revival of a dissolved company upon the rights of the Crown.

The claim of the Crown to the assets of a company following a technical dissolution was considered by the Supreme Court of Canada in A.G. of B.C. v. Royal Bank and Island Amusement $C o .^{23}$ Rather than merely ruling that a subsequent order reviving the dissolved company defeated the rights of the Crown, the court ruled that the Crown never acquired any rights $a b$ initio: ${ }^{24}$

Reading these sections together, therefore, the effect of the order was, as stated in subsection 1 of section 199, that there upon the company shall be deemed to have continued in existence ... as if it had not been struck off.

The enactment in subsection 2 of section 200 that unless the Court otherwise orders, the order shall be made without prejudice to the rights of parties acquired prior to the date on which the company is restored by the Registrar, when read in the light of the terms of section 199 that "the company shall be deemed to have continued in existence" causes no difficulty as I have concluded that the making of the order in 1928, striking the company from the register, never gave the Crown a right to the money as bona vacantia. (It should be added that the insertion in the order restoring the company to the register, of the "without prejudice" clause adds nothing to the effect of subsection 2 of section 200.)

Such a right arises only when there is no other owner, and how can it be said that the money on deposit was without an owner when the company was not really dead for all purposes?

... can it be said that the "dissolution" was an end of the company for all purposes, and particularly for the purpose of the applicant's contention that the money on deposit in the bank ceased to have an owner, so as to permit the operation of the doctrine of bona vacantia? I conclude that the answer must be in the negative and that is sufficient to dispose of the present appeal.

These views obviously cause immense practical and theoretical difficulties. What would be the result if the dissolved company was never revived by being restored to the register? Would the dissolved company nevertheless remain the legal owner of the goods? How could the dissolved company enforce its rights to the goods?

The preceding difficulties could have been avoided if the court had simply determined that the effect of a revival order was to re-vest in the revived company all of the property which the Crown had acquired as bona vacantia. ${ }^{25}$ Alternatively, the court could have utilized a legal fiction:

22. Re Jolin et al and Lart Investments Ltd, supra n. 20.

23. Supra n. 6.

24. Id. at 469 and 471.472 .

25. Davis J. dismissed this possibility with the following comments, id. at 477 :

But personally I find it exceedingly difficult, dealing with the matter as one of practical administration, to think of the Crown's right to ownership of goods in the character of bona vacantia in terms of a qualified or defeasible title. It appears to me to be a contradiction in terms to regard the property of a company as being without an owner and at the same time to recognize the possibility that at some undefined period of time in the future the corporation may be revived and the title of the Crown defeated. 
the effect of a revival order is to deem retrospectively that the Crown never acquired the property to begin with because the company is deemed not to have been dissolved. ${ }^{26}$ While such a legal fiction resembles somewhat the actual result reached by the court, it is nevertheless fundamentally different in nature, for such a fiction admits that until a revival order is obtained, the company is dead for all purposes.

The only remaining issue which would cause difficulty, if such an analysis were adopted, would be the proviso contained in s. 189(1) and in the statute under consideration in the Royal Bank case, a proviso to the effect that revival is not to prejudice the rights of other parties. It may have been the desire to avoid this latter issue which led the court to resolve the case as it did. But as can be readily demonstrated, the "without prejudice" proviso does not cause an insurmountable problem. The proviso should not be interpreted as protecting the rights acquired by the Crown, for a very simple reason: ${ }^{27}$ what would be the purpose of seeking revival, which may be sought by creditors inter alia, if a company restored to life no longer possessed any property or assets, these having been acquired by the Crown? The absurdity of such a result can mean only one thing: the proviso was inserted to protect third party rights and was never intended to embrace the rights acquired by the Crown under the rules as to bona vacantia and escheats.

\section{The General Dissolution}

Upon a general dissolution, the Crown can claim the undistributed property of the dissolved company (assuming again that the rules as to bona vacantia and escheats apply in Alberta). Within one year, such a dissolution can be declared void pursuant to s. 272 of The Companies Act. In England, the theory accepted by the courts is that such an order re-vests the property in the company; or rather, through a statutory fiction reaching backward, causes it never to have vested in the Crown ${ }^{28}$ But as emphasized in note 26, the right to bona vacantia under the modern English Companies Act is now statutory in nature, expressly made subject to possible defeasance by a revival order.

Despite such a difference, the same result would surely prevail in Canada due to the rationale advanced above: what useful purpose would be served by reviving a company under s. 272 if the company no longer possessed any property or assets? Only if property is restored to the company does the revival order provided by s. 272 make any real sense.

Beyond the statutory revival period (one year in Alberta), there would exist no means of defeating the rights acquired by the Crown.

\section{4. $C B C A / A B C A$}

The provisions of the CBCA and ABCA seem to resolve all of the prob-

26. In England, it has been held that such a revival order has precisely this effect: $R$ e Cambridge Coffee Room Association $L t$. [1952] 1 All E.R. 112. But it is to be noted that the situation is not entirely equivalent, for two reasons: (1) the right of the Crown to bona vacantia is a statutory right under s. 354 of the English Companies Act, 1948 (U.K.), 11 and $12 \mathrm{Geo}$. VI, c. 38, expressly made subject to defeasance by a possible revival order; (2) the revival section does not contain a "without prejudice to the rights of other parties" proviso.

27. David Phillip Jones, "The Effect of a 'Technical' Dissolution of a Company and Its Implications for the Doctrine of Lapse" (1978) 3 E.T.R. 2 at 5.

28. Re. C.W. Dixon Ltd. [1947] Ch. 251. 
lems involved in this section. Under s.221(1) of each Act, any property of a dissolved corporation which has been overlooked vests in the Crown (in right of Canada under the CBCA and in right of Alberta under the ABCA). ${ }^{29}$ Section $221(1)$ of the ABCA reads as follows:

221.(1) Subject to sections $219(2)$ and 220, property of a body corporate that has not been disposed of at the date of its dissolution under this Act vests in Her Majesty in right of Alberta.

Upon the revival of a dissolved company under both Acts, a scheme is set up in s. 221(2) for the return of property to the company either in specie or in money's worth:

(2) If a body corporate is revived as a corporation under section 201 or section 202, any property. other than money that vested in Her Majesty pursuant to subsection (1), that has not been disposed of shall be returned to the corporation and there shall be paid to the corporation out of the General Revenue Fund

(a) an amount equal to any money received by Her Majesty pursuant to subsection (2), and

(b) if property other than money vested in Her Majesty pursuant to subsection (1) and that property has been disposed of, an amount equal to the lesser of

(i) the value of that property at the date it vested in Her Majesty, and

(ii) the amount realized by Her Majesty from the dispostion of that property.

The scheme very carefully assures that the Crown cannot suffer a loss from the return of the property.

Only two minor difficulties subsist. First, it was noted above that property held on trust by a dissolved company might vest in the Crown, but remained subject to the trust. Would this result also be reached under the statutory provisions? This is somewhat uncertain and it may be that the beneficiaries of the trust would have to seek revival under s. 201 to assure that the trust remained in effect. Second, could a shareholder of a dissolved company seek revival solely to allow distribution of overlooked assets? The answer to this would hopefully be affirmative, for s. 201 is wide enough to accomplish this, and the comments of the framers of the proposed ABCA make it clear that s.221(2) was inserted for that very purpose. ${ }^{30}$ As such, the philosophy underlying the 1917 decision of Embree v. Millar has won full acceptance.

\section{The Obligations and Rights of the Dissolved Company}

1. General

Now that the rights of the Crown have been considered, attention may be focused upon exactly what property rights may vest in the Crown and may therefore ultimately be returned to the dissolved company upon its revival. That is, the precise effect of dissolution upon assets and liabilities will be examined.

According to the older English authorities, "the debts of a corporation, either to or from it, are totally extinguished by its dissolution". However, this view has been critically questioned by later authorities. Darling J. in Re Higginson \& Dean casts doubts upon it, referring to the

29. The vesting is made subject to s. 219(2), discussed infra, and to s. 220 , which merely assures that the portion of property remaining undistributed because a shareholder cannot be found can be claimed by that shareholder.

30. Supra n. 3 at 307.

31. Blackstone, Comm. 484; Coxon v. Gorst [1891] 2 Ch. 73; Re Westbourne Grove Draper Co. (1878) 39 L.T. 30; Russian \& English Bank v. Baring Bros., supra n. 14 at 518 (per Lord Atkin); Kyd, Corporations at 516; Grant, Corporations at 303. For a more extensive discussion, see: Wegenest, Canadian Companies (1931) at 108-111. 
contrary American position. ${ }^{32}$ The Alberta Court of Appeal in Embree v. Millar reiterated these views and adopted the American position. ${ }^{33}$

The problems in this area arise in part due to an issue ultimately tied in with it, the status of a dissolved company in the courts. If a dissolved company has no means of acquiring the status to maintain actions in the courts, or if it cannot be forced to acquire such status in order to defend actions against it, obligations owed to it or owed by it cannot be enforced (except possibly by the Crown pursuant to its rights).

Overall, while some doubts may remain, it can be said that the better view is that a company's debts (to it or from it) are not extinguished by its dissolution. The conclusion reached by Lawrence J. in one English case represents the consensus of opinion: ${ }^{34}$

The statement in Blackstone's Commentaries, vol. i., p. 484, that the debts of a corporation either to or from it are totally extinguished by its dissolution and similar statements made by Kyd and Grant must either be read as having reference merely to the rights and liabilities of the individual corporators or else are obsolete.

\section{The Technical Dissolution}

If doubts have existed as to the overall position, this is not so in regard to a technical dissolution. It can safely be said that the obligations and debts owed to or from a company struck off the register are not extinguished..$^{35}$ Any other view would be difficult to defend, for part of the purpose of a s. 189(1) revival order, which may be sought by the company or its creditors, is to permit the enforcement of such obligations.

But until the dissolved company has been restored to the register, it cannot maintain actions; however, the court, upon being informed of the dissolution, will merely stay proceedings until the company has been restored..$^{36}$ Once restored, the curative provisions of s. $189(1)$ apply and will erase any disability of the company which may have occurred if it obtained judgment or pursued steps while dissolved..$^{37}$ The fact that such a disability will be removed is not a prejudice to the rights of the opposite

32. In Re Higginson \& Dean, supra n. 6 at 330 et seq.

33. Embree v. Millar, supra n. 12.

34. In Re Wells-Swinburne Hanham v. Howard, supra n. 14 at 51; for the same conclusion, see also Wegenest, Canadian Companies, supra n. 31 at 109; but see Russian \& English Bank v. Baring Bros., supra n. 31 where Lord Atkin specifically disagrees with Lawrence $J$. and reiterates the historical view.

35. Leask Cattle Co. v. Drabble, supra n. 6; Pocock Floors Ltd. v. Holmes Construction Ltd. et al [1971] 1 W.W.R. 394 (Alta. D.C.); International Mining Syndicate v.Steward (1914) 48 N.S.R. 172 (N.S.C.A.); Sutherland v. Strawberry Valley Stock \& Farm Produce Co. [1922] 3 W.W.R. 241 (Sask. K.B.); Re Porter Art \& Music Co. (1913) 9 W.W.R. 30 (Sask. S.C.); see also Re Lindsay Bowman Ltd. [1969] 1 W.L.R. 1443 (Ch. D.); Tyman's Ltd. v. Craven, supra n. 9.

36. Berroy Holdings $L t d$ v. Cowen et al (1978) 5 A.L.R. 5 (Alta. D.C.); Pocock Floors Ltd. v. Holmes Construction Ltd. et ah supra $\mathrm{n}$. 35; Sutherland v. Strawberry Valley Stock \& Farm Produce Co., supra n. 35; Spray Construction Co. v. M.N.R. (1950) 2 Tax A.B.C. 170; Bute Logging Co. v. Sanders (1952) 5 W.W.R. 142 (B.C.S.C.).

37. Leask Cattle Co. v. Drabble, supra n. 6; Pocock's Floors Ltd. v. Holmes Construction Ltd. et ah supra n. 35; Tyman's Ltd. v. Craven, supra n. 9. 
parties within the meaning of $s .189(1)$, for $s .189(1)$ has been interpreted as being intended to remove this very disability. ${ }^{38}$

Hence, the position of a company following a technical dissolution appears to be fairly straightforward. The only remaining unresolved issue is the following: what if, for some unlikely reason, a revival order under s. 189(1) is refused? The company could not acquire any status in the courts. As this situation resembles the one arising when revival is no longer possible following a general dissolution, it will be discussed below, in Section 3(b).

\section{The General Dissolution}

It appears from the general discussion above that the obligations to and from a company are not extinguished by a general dissolution, though this is less certain than in the case of a technical dissolution. The situation will be examined in more detail in two stages: first, the situation arising when the dissolution is declared void under s. 272, and second, the rights of the Crown beyond the revival period.

\section{(a) Void Dissolution}

The effect of declaring a dissolution void, pursuant to a s. 272 order, has received little judicial consideration in Canada. In England, its purpose, as described by authorities, is to make possible a distribution of assets which belonged to the company before the dissolution and which were overlooked ${ }^{39}$ and also to allow the dissolved company to regain assets or enforce claims which belonged to it at the date of its dissolution. ${ }^{40}$ If this view is accepted in Canada, a ready means of enforcing obligations owed to a dissolved company exists for a year after the date of the dissolution. It would also appear that creditors fall within the class of interested persons allowed to seek revival under s. 272 so as to enforce obligations owed by the dissolved company. ${ }^{41}$

An order made under a s. 272 provision has, however, been interpreted as lacking a full retroactive effect, in contrast to a revival order made under s. 189(1). Such a distinction was drawn by the House of Lords in Morris v. Harris: ${ }^{42}$

38. Pocock Floors Ltd. v. Holmes Construction Ltd. et ah supra n. 35 (Alta. D.C.); but see Berroy Holdings v. Cowen et ah supra n. 36, where Feehan J. says:

The action is not the company but something owned by the company. The action does not die when the company is dissolved but the company may not proceed with it before restoration. In my view, the defendants had gained no right of dismissal as at the time of this application. The only right they had gained was the right not to be faced with a further step in the action by the plaintiff prior to the restoration order and the filing thereof.

Such words could be interpreted as meaning that the revival order will allow the company to continue its action, but will not validate steps taken in the interval between dissolution and restoration. Such an interpretation would be contrary to the other authorities.

39. In Re Spottiswoode, Dixon \& Hunting, Ltd. [1912] Ch. 410; Palmer, Company Law, supra $\mathrm{n} .10$ at 939.

40. Pennington, Company Law, supra n. 10 at 726.

41. In Re Belmont \& Co. Ltd. [1952] 1 Ch. 10; In Re Spottiswoode, Dixon \& Hunting, Ltd., supra n. 39.

42. Supra n. 9 at 269 (H.L.). 
[A]n order under the section made, it may be, as long as two years after a dissolution which up to that moment was completely effective, is not at once and as of course to ratify acts done during the interval, which, if done at all, must necessarily have been acts of mere usurpation, by a liquidator or other pretended agent with no office knowingly done on behalf of a company which had no existence. On consideration, it appears, I think, clear that automatically to validate such acts as being the acts of a duly constituted officer on behalf of a duly incorporated company might involve consequences too disastrous to be even envisaged. These are avoided by the terms of the section. The company is restored to life as from the moment of dissolution but, continuing a convenient metaphor, it remains buried, unconscious, asleep and powerless until the order is made which declares the dissolution to have been void. Then, and only then, is the company restored to activity.

The result is that a revival order under s. 272 does not render valid proceedings taken after the dissolution of the company; acts done or litigation conducted in the company's name after a general dissolution are not validated and made binding upon it and other parties, but must be commenced afresh. ${ }^{43}$ But apart from this absence of a full retroactive effect (and the limitation period problems it may create), the ultimate result would appear to be similar: once revived, obligations owed to the company, and presumably, obligations owed by the company, can be enforced.

\section{(b) Rights of the Crown Beyond the Revival Period}

Section 272 of The Companies Act limits the possibility of revival to one year. ${ }^{44}$ Beyond one year, the dissolved company is permanently and irrevocably dead. It will be incapable of enforcing any obligations owed to it; creditors will be unable to enforce obligations against it. An analagous situation would arise if, for some reason, the courts refuse to grant an order restoring a company to the register under s. 189(1) (subject to the issue of whether bona vacantia applied at all due to the technical dissolution aspect).

Assuming that the rules as to bona vacantia and escheats apply in Alberta, the Crown would acquire all of the company's property and assets remaining undistributed. What remains unclear is: would the Crown be able to maintain all the actions which the company could have maintained had it not been dissolved? Or would its rights in some manner be limited?

These questions have not been definitely resolved. The English Court of Appeal has rejected the theory that the Crown can only enforce obligations where it alleges a trust, ${ }^{45}$ disapproving of a dictum expressed in an earlier case that it would "be judicial legislation to declare the Crown entitled to maintain actions in such cases, except where it can allege a trust". ${ }^{46}$ Beyond that, the situation is unclear. The cases which have come before the courts have all involved actions or rights with respect to which it would have been very inequitable to allow the other party to maintain that its obligations were unenforceable at the instance of the Crown; for example, funds in bank accounts and reversions of leasehold interests. But would the courts extend the right of the Crown to maintain an action to all forms of actions, such as a claim for breach of contract or a claim in tort? And if the answer is yes, could the other party counterclaim or at-

43. Id.; Re Lewis and Smart, Ltd. [1954] 2 All E.R. 19.

44. In England, where the period is two years, it has been held that an order may be made after the expiration of two years if the application is made within two years: $R e$ Scad Ltd. [1941] Ch. 386.

45. In Re Wells-Swinburne Hanham v. Howard, supra n. 14.

46. In Re Higginson \& Dean, supra n. 6 at 332. 
tempt to set up some other claim against the dissolved company by way of set-off? The complex problems to which such a result would lead support the view that the rights acquired by the Crown should be limited in some manner.

\section{4. $C B C A / A B C A$}

The CBCA and the proposed ABCA solve many of the problems discussed above. The unique revival order under s. 202 or s. 201 renders obsolete, it is hoped, the distinction drawn between a technical and a general dissolution. As such, a uniform approach can be adopted and examined in its component parts more simply.

\section{(a) Actions Against the Dissolved Company}

Under s. 219(2) of the proposed ABCA (s. 219(2) of the CBCA), an action already commenced against the dissolved corporation may be continued and a new action may be commenced within two years of the dissolution. This removes the need to seek revival of the corporation, as is presently necessary under The Companies Act. Any property which has vested in the Crown is expressly made subject to the rights created by s. 219 . Hence, as long as s. 219(2) proceedings are possible, the situation is straightforward and any doubts as to whether dissolution extinguishes obligations owed by the corporation are removed.

Beyond the two year period, however, actions can no longer be initiated. As a result, proceedings against the corporation cannot be initiated or pursued unless the corporation has been revived under s. 201 . Would someone seeking to revive the dissolved corporation merely for the purpose of taking legal proceedings against it have status, as an "interested person", to seek such a revival under s.201? To the extent that s. 201 re-incorporates ss. $189(1)$ and 272 of The Companies Act, the answer would appear to be affirmative. The comments of the framers of the ABCA support this conclusion. ${ }^{47}$ As a result, obligations owed by the corporation would not be extinguished by dissolution at all.

\section{(b) Actions by the Corporation}

Section 219(2) also provides that actions commenced by the corporation prior to its dissolution may be continued. To that extent, any doubts as to whether dissolution extinguishes obligations owed to the corporation are removed. Section 219(2) does not, however, provide for initiation of ac-

47. Institute of Law Research and Reform, Proposals for a New Alberta Business Corpora. tions Act (Report No. 36, Vol. 1, August, 1980) at 162-163:

We do not doubt the appropriateness of our proposals with regard to any property and rights held by the corporation at the time of its dissolution. The creditors and shareholders of a corporation are the persons who are and should be entitled to the benefit of its property and rights, and there is no reason why the Crown or anyone else should acquire them beneficially merely because the corporation is dissolved. $S$. 202 would reinstate the corporation in beneficial entitlement, and s. 221 would preserve the legal title in the meantime and revest it in the corporation upon revival.

We also do not doubt the appropriateness of our proposals with regard to obligations of the corporation which exist at dissolution. Under s. 219 of the draft Act, actions and proceedings against the corporation on foot at the time of dissolution might be continued, and for two years new proceedings might be commenced, as if the corporation had not been dissolved; and thereafter (or, indeed, at any time) "any interested person," which term we think would include anyone with a claim against the corporation, might apply for a revival order which would have the effect of making the corporation liable for those obligations. While there may be some procedural difficulties in suing a dissolved corporation we think that these can be overcome. 
tions by the corporation after dissolution. Instead, revival would have to occur under s. 201. Presumably, s. 201 would be interpreted as permitting revival for such a purpose, for s. 201 to a large extent re-incorporates the language of s. 189(1) of The Companies Act. As such, obligations owed to the corporation ought to survive the dissolution.

However, a very important departure from existing principles should be noted in relation to $\mathbf{2}$.201. Section 201 of course combines the two types of revival possible under existing law, under ss. 189(1) and 272 of The Companies Act, and "rolls them up" in one procedure. But as seen above, those two provisions have different retroactive effects: s. 189(1) is fully retroactive, validating all acts of the company undertaken while dissolved, subject only to the rights of other parties; s. 272 has been interpreted as having a more limited retroactive effect, not curing the disabilities the company suffered while non-existent (Morris v. Harris). The question which naturally arises is the following: which type of retroactive effect will the courts give to $s .201$ ? While this problem will be returned to, infra ${ }^{48}$ it would appear that the more limited retroactive effect of s. 272 will be ascribed to revival. In Manitoba, the equivalent revival provision has been interpreted as not having full retroactive effect, thereby not curing steps taken while the corporation was dissolved. ${ }^{49}$ The court founded its conclusion largely upon the fact that the provision in question (similar to s. 201) did not possess words to the effect that upon revival, a corporation is deemed to have continued in existence as if it had not been dissolved. The absence of such words may indeed be indicative that such a result was intended, and may reflect the view that any actions undertaken while a corporation is dissolved are more likely to be those of a mere usurper, given the more stringent procedures for striking a corporation off the register. On the other hand, whether such a rationale is sufficiently important so as to require a corporation to repeat any steps taken in the interval between dissolution and revival is uncertain; indeed, the extension of this principle may have unintended injurious consequences which will be discussed infra.

\section{(c) The Rights of the Crown}

The uncertainty as to what possible actions the Crown may acquire as a result of its rights is not resolved by the CBCA or the proposed ABCA. These Acts fail to define "property". Hence, if for some reason revival was refused and the Crown attempted to claim any or all property rights possessed by the dissolved corporation, the courts would be faced with the same issues as presently exist.

D. The Extent of Revival and Its Effects on the Rights of Other Parties

1. General

The most critical and difficult issue in this whole area concerns the effects of revival on the rights of other parties. While this issue has been incidentally touched upon above, it will now be discussed in much greater

48. Infra, Section D. 4.

49. Steven Kulba Enterprises Ltd. v. Viking Investments Ltd. (1978) 87 D.L.R. (3rd) 541 (Man.Q.B.). Strictly speaking, the comments of Morse, J. are obiter, for the corporation had not in fact been revived. Furthermore, with the greatest of respect, the analysis of past case law relied upon to reach the conclusion suffers from a failure to appreciate the different retrospective effects the old provisions led to. 
detail. Since the courts in Canada have been confronted with this issue in regard to revival under s. 189(1), the bulk of the analysis is contained in the next section.

\section{Revival under S. 189(1)}

The difficulties to which revival leads can easily be illustrated by a simple factual example: a testator makes a will and leaves property to Company $\mathrm{X}$; Company $\mathrm{X}$ is struck off the register and is dissolved; the testator then dies; Company $\mathrm{X}$ is then revived. Should the revived company be allowed to take the bequest, thereby defeating the opportunity residuary beneficiaries had of taking?

The above example, essentially the facts faced by the court in Montreal Trust Co. v. Boy Scouts Foundation ${ }^{50}$ raises directly the inherent difficulties created by $\mathbf{s} .189(1)$. Such difficulties cannot be avoided, for $s$. 189 (1) sets out to accomplish two contradictory purposes: first, to place a company that has been revived in the same position it would have been had it not been dissolved, and second, to preserve the rights of other parties acquired during the period of dissolution. Three possible solutions can be attempted in order to reconcile those two objectives; each of these is fraught with difficulties and weaknesses. Each solution will be examined in turn.

\section{(a) Complete Protection of Third Party Rights}

The advocates of this position would give a very literal meaning to $\mathrm{s}$. 189(1) and conclude that the "without prejudice" proviso was designed to afford complete protection of any rights acquired by another party. This extreme view was rejected by Ruttan J. in the Boy Scouts case, supra.

However meritorious the position may be, it cannot be given full effect. Two examples already considered will suffice to demonstrate this. First, the Crown could argue that its rights are prejudiced by any revival order which would re-vest property in the company. ${ }^{51}$ Second, other parties could argue that revival prejudices their rights by allowing a revived company to regain a status permitting it to continue or to initiate actions to enforce obligations owed to the company by these parties. ${ }^{52}$ Obviously these "rights" were not meant to be protected by the proviso in s. 189(1), for revival would be an exercise in futility if the assets and rights of action were stripped from a revived company. Hence, this alternative is not feasible, and the courts have been forced to delineate some of these situations so as to exclude them from the operation of the proviso.

(b) Limited or Minimal Protection of Third Party Rights

The opposite extreme emphasizes the rights of the revived company at the expense of the rights of third parties. In order to avoid judicially eliminating the "without prejudice" proviso, it is avoided $a b$ initio (as the Supreme Court of Canada did in regard to the Crown's claim of bona vacantia) or it is given a restrictive interpretation. One of these interpretations, developed by Davis J. and adopted by Ruttan J. in the Boy

50. Supra n. 6.

51. See the discussion supra, Section B.

52. See the discussion supra, Section C. 
Scouts case, is that the proviso merely protects the rights acquired in dealings with the dissolved company. ${ }^{53}$

[I]t becomes apparent that the without prejudice clause in the statute, and which is found in the order restoring the respondent company, is intended to preserve legitimate claims of third parties which have arisen subsequent to the date that the company was stricken off the register because officers and agents of the company may not have heard of the striking of the name of the company from the register and may have gone ahead for some time carrying on the operations of the company in absolute good faith without notice or knowledge that the Registrar had stricken the name of the company off the register. That I believe is a fair interpretation to be put upon the without prejudice clause.

A second interpretation, developed by McPhillips J.A. in a judgment in dissent on other grounds, is far less restrictive; nevertheless, it would only protect the rights of innocent third parties who have indirectly obtained rights as against the dissolved company: $:^{54}$

It is to be observed though that when the appellant company was restored to the register the apt words of the statute must be given effect to "shall be deemed to have continued in existence." This must result in reclothing the appellant company with all the assets subject only to the recognition of all rights acquired in the interim of time and as between the original parties, i.e., as between the lessor and the lessee the demise revives or more properly must be deemed never to have reverted, save in the way of the preservation of existing equities as it is not reasonable to assume that the Legislature intended to affect innocent third parties.

Whatever restrictive interpretation is taken, it can be criticized for its undue emphasis on the protection of the rights of the revived company at the expense of other parties. As well, the means adopted to reach such a conclusion lead to legal difficulties as described above and excellently commented upon elsewhere.$^{55} \mathrm{~A}$ third criticism of so interpreting s.189(1) can be offered: it places undue emphasis on some of the English cases which have tended to give full retrospective effect to a s. 189(1)-type of revival $;^{56}$ such reliance disregards a fundamental difference between the Alberta section and the English section, for the latter does not contain a "without prejudice" proviso.

\section{(c) Discretionary Approach}

The difficulties with each of the above extremes suggest that a compromise approach might be feasible and could be developed by the courts. The courts could adjust the rights of the various parties as seems just, convenient and reasonable for all parties concerned, taking into account the various circumstances (e.g. type of dissolution involved, motives for the revival). Variations on the fact situation of the Boy Scouts case illustrate that different results should flow depending upon the answers to these questions: ${ }^{57}$ Was the foundation revived solely to receive the

53. A.G. of B.C. v. The Royal Bank of Canada and Island Amusement Co. Ltd, supra n. 6 at 477-478 (S.C.C.).

54. B.C. Thoroughbred Association v. Brighouse [1922] W.W.R. 665 at $672-673$ (B.C.C.A.); contra: see the judgment of Galliher J.A. at 669 .

55. See Jones, supra n. 27 for a very critical analysis of the Boy Scouts case and a discussion of the authorities relied upon in that decision.

56. In England, the section has been interpreted as designed to achieve to the fullest extent possible the "as you were position": Tyman's Ltd. v. Craven, supra n. 9; In Re Donald Kenyon Ltd. [1956] 1 W.L.R. 1397; Re Lindsay Bowman Ltd. [1969] 1 W.W.R. 1443. Despite these authorities, some courts have held or indicated that the courts retain an ultimate discretion to insert clauses to prevent prejudice to innocent parties: In $R e$ Rugby A uto Electric Services L td. unreported (see Buckley. The Companies Acts (13th ed. 1957) 1364); Re Boxco Ltd. [1970] Ch. 442. If the English courts have such a discretion, a fortiori so do the Canadian courts.

57. See infra. Revival Under S. 272 and an analogous factual situation faced by an English Court where a different result was reached. 
legacy? Did it continue to operate in the interim? How negligent were the officers and directors of the company in allowing a technical dissolution to take place?

The inescapable trade-off for such a discretionary approach, openly admitted by the Courts, would be uncertainty. As well, such a position, it is admitted, would come close to judicial legislation, given the present wording of the provisions involved.

\section{Revival under Section 272}

The Canadian courts have not considered s. 272 as it affects third party rights. The English courts have considered such a provision and have concluded that orders under a s. 272-type revival are discretionary and that the rights of third parties should be taken into account.$^{58}$ Furthermore, in a decision highly relevant to the Boy Scouts case, it was held that an application to revive a company generally dissolved should be refused if its purpose was to enable the dissolved company to take a bequest under a will and thereby divest the next-of-kin of their interests. ${ }^{59}$ Perhaps such a viewpoint is reconcilable with the underlying rationale of the Boy Scouts case, for it could well be that a different result should flow depending upon the intentional or non-intentional dissolution of a company.

\section{4. $C B C A / A B C A$}

It is very uncertain to what extent the CBCA and the proposed ABCA can be seen to resolve the basic problems discussed above. Some of the comments of the framers of the ABCA indicate that they were not prepared to attempt to resolve the issue, given the endless variations which are possible, but preferred to allow the courts to work out a practical solution when a specific case arises ${ }^{60}$ On the other hand, two developments can be seen as leading the courts to favor the interests of other parties above the interests of the dissolved corporation. The first of these is the more rigorous procedure for striking a corporation off the register; the effect should be that it is very unlikely that a corporation would continue to conduct business without a responsible official being aware of the dissolution. The exceptional case, however, could subsist. The second factor has already been examined: the view that revival will not retrospectively validate actions taken in the interval between dissolution and restoration, but will leave the status of the corporation in that interval as non-existent. Some of the comments of the framers of the ABCA could be interpreted as intending such a result. ${ }^{61}$

58. In Re Servers of the Blind League [1960] 1 W.L.R. 564 (Ch. D.).

59. Id.

60. Supra n. 47 at $162-163$.

61. Id., where the framers of the ABCA state:

We are more doubtful about rights and obligations which, if the corporation were not dissolved, would accrue either to a corporation or to others during the period after it is dissolved and before it is revived. The draft Act, like the CBCA, does not specifically deal with the intervening period. As we have already said, there is authority for the proposition that acts during the period of dissolution are not validated by a company's restoration to the register under ACA s. 189, and the words "dissolved" and "revived" appear to be stronger in favour of the proposition than the ACA words "struck from the register" upon which it is based, but a firm statement about their effect will have to await judicial interpretation. There is more doubt as to the law relating to things done by others which might be said to affect the company's rights and obligations and the rights of third parties which may arise during the interval. Our inclination, however, is to leave well enough alone, and we have done so by following the CBCA language. 
Nevertheless, could the adoption of such a conclusion lead to injurious consequences which should not prevail? If the conclusion is merely intended to assure a more complete protection of the "rights" of other parties, with some limitations, it is difficult to criticize such a policy-oriented choice; that is, a shifting of the balance of the interests protected can be supported. But has the shifting gone too far? Does complete nonexistence, despite subsequent revival, mean that all obligations, contracts, etc., undertaken in the interval are invalidated? That actions in court undertaken by the entity must all be commenced afresh rather than merely stayed? That, indeed, anything done is rendered a complete nullity? These difficult questions hopefully will be addressed and considered by the courts in interpreting the revival provisions.

\section{SUMMARY AND CONCLUSION}

It has been seen that several difficult issues, some created by old principles unsuited to modern times, have been faced by the courts in considering dissolution and revival under either $s$. 189(1) or $s$. 272 . The resulting case law developed a concept that two different types of dissolution occurred under companies' legislation; such a concept needlessly concentrated on the dissolution aspect of the issue rather than on the revival mechanism and the true meaning to be given to the protection of other parties' rights when revival occurs. Hopefully, the unique revival mechanism of the CBCA/ABCA will be interpreted as laying to rest that concept and will lead the courts to conclude that a dissolved corporation is indeed "dead for all purposes" until it is revived.

Several issues, such as the rights possessed by the Crown, the extinction or non-extinction of obligations owed by and owed to a corporation were then examined. Again, it was seen that the CBCA/ABCA solve many of the problems associated with these issues, adopting a scheme whereby the Crown acquires defeasible rights and eliminating, it is hoped, the doubts as to whether dissolution terminates obligations owed by, or to, a corporation. The major unresolved issue here concerns the extent of the Crown's rights should a corporation never be revived, an issue with which the courts may never be confronted, given the absence of a time limitation for revival.

Finally, the most important and difficult issue was addressed, that of the retrospective effect of revival upon the rights of other parties. It was seen that certain "rights" were never intended to be protected in a revival and that the courts at times needlessly avoided the issue. The CBCA/ABCA would re-incorporate such an analysis. On the other hand, the courts at times may have erred in over-protecting the dissolved company's rights by developing the concept of the technical dissolution. The CBCA/ABCA rejects such an analysis and attempts to provide greater protection to the rights of other parties. But in attempting to achieve those worthy objectives, they may have gone too far in unnecessarily cutting down the retrospective effect of revival. 